\title{
IDENTITY IN LAW: THE SECOND MEDICAL USE AND THE DRUGS FOR NEGLECTED DISEASES ${ }^{1}$
}

Marcos Vinício Chein Feres

Ph.D in Economic Law. Associate Professor of Law School UFJF. Pesquisador de Produtividade PQ2 CNPq. mvchein@gmail.com

\begin{abstract}
This paper is dedicated to presenting a normative political institutional approach, which may creatively reconstruct the hermeneutics of the Brazilian Industrial Property Rights Act in the specific case of the second medical use of known substances in the matter of drugs for neglected diseases. However, the fact of having the same chemical substance, as a point of departure, might signify that the incremented drug does not fulfil the requisites of patentability according to the traditional legal deduction practised in Brazilian courts. Methodologically, the theoretical reference here applied consists of the fusion between the ideas of law as integrity, developed by Dworkin, and law as identity, complemented by Taylor's social theory of identity and Bankowski's proposal of living lawfully. In fact, this methodological approach proposes the reconstruction of a system of analytical concepts based on contemporary legal theory in order to legitimatise public decisions whose purpose is to foster the research and development of drugs for neglected diseases. In this context, the legal concepts of novelty, non-obviousness and industrial application listed in the Brazilian Industrial Property Rights Act are reinterpreted according to the theoretical reference of identity in law.
\end{abstract}

Key words: Law as identity - second medical use drugs - drugs for neglected diseases.

\section{INTRODUCTION}

The theoretical basis of this paper is dedicated to the presentation of a normative political institutional approach, which may creatively

1 This paper has the financial support of Fundação de Amparo da Pesquisa do Estado de Minas Gerais (FAPEMIG) and Conselho Nacional de Desenvolvimento Científico e Tecnológico (CNPq). 
reconstruct the hermeneutics of the Brazilian Industrial Property Rights Act. The object of study here is the legitimacy of patentability of the second medical use of known substances as a means of fostering the development of drugs for neglected diseases. According to the Médecins Sans Frontières (2010), the problem of neglected diseases is related to the lack of economic interest on the part of pharmaceutical industries in developing more effective drugs to treat diseases, such as, malaria, Chagas disease, leishmaniasis, and tuberculosis. These are known as neglected diseases, for there is no direct market interest in investing large sums of money to develop drugs which may contribute to the prevention and cure of these diseases.

The hypothesis which structures the study of the legitimacy of second medical use drugs is based on the possibility of legally analysing if the patent for a second medical use drug may directly influence the process of innovation, considering the aim of the Brazilian Industrial Property Rights Act, i.e., implement the right to scientific and technological development. However, the fact of having the same chemical substance, as a point of departure, might signify that the incremented drug does not fulfil the requisites of patentability according to the traditional legal deduction practised in Brazilian courts. In this vein, different scholars consider the second medical use of a known substance an illegal attempt to extend the duration of the patent, disregarding other social impacts of the second medical use as well as the fundamentals of industrial property rights.

Methodologically, the theoretical reference here applied consists of the fusion of the theory of law as integrity, developed by Dworkin, and the idea of law as identity, complemented by Taylor's social theory of identity and Bankowski's proposal of "living lawfully". Integrity plays an essential role in the reconstruction of a methodological tool for understanding the double dimension of the right to patent a second medical use drug. The idea of law as integrity reinforces that law is an interpretive practice, which requires the intertwining between legal rules per se and institutional morality. However, in order to concretise the moral dimension as a relevant criterion of legal interpretation, it is important to shed light on an old debate between legalism and legality. In this context, Bankowski demonstrates that the tension between love and law affects the interpretive legal practice. Going beyond the Dworkian theory of law as integrity does not mean abandoning his theoretical presuppositions but reinserting them into a context of identity in law.

This new theoretical perspective serves as a trigger to methodologically analyse the possible inconsistency in the argument that second medical use drugs are illegal per se or they represent an illegal attempt to monopolise the use of patented drugs for a longer period of time. A basic question arises: is it legally valid to patent second 
medical use drugs, according to the Brazilian Property Rights Act? In this vein, two other questions need to be answered immediately after the first one already stated: is there a legal gap in the specific legislation that might be morally inconsistent? Is it legally and logically coherent through ordinary interpretation to validate the second medical use as an incentive to develop and produce drugs for neglected diseases?

In fact, this methodological approach proposes the reconstruction of a system of analytical concepts based on contemporary legal theory in order to verify if public decisions whose purpose is to foster the research and development of drugs for neglected diseases are viable through mere interpretation by administrative agencies, taking for granted the way the actual legislation is conceived. The limits of the Brazilian administrative agency, National Institute of Industrial Property Rights (INPI), responsible for analysing and approving requests for patenting innovative products or processes submitted as a means of acquiring the legal monopoly over them for twenty years, must be tested and verified. The methodology of data analysis in the qualitative research here designed is formerly constructed based on the assertion that law, in its best light, has to be conceived as an interpretive practice. The interpretive practice requires working on the tension between legalism and love (solidarity). Once data related to the development of second medical use drugs is collected, it is methodologically accurate to conclude that there is no logical relationship between the second medical use drugs and the drugs for neglected diseases. The interpretive practice of the Brazilian Industrial Property Rights Act is invariable in spite of the kind of disease the second medical use drug can be applied to.

Stemming from this methodological approach, the paper will be divided into three major parts. First of all, the theoretical reference and the qualitative methodology will be structured as a point of departure for reconstructing the essence of legal interpretation that may be applied to the case of second medical use drugs. Secondly, the patentability of the second medical use of a known substance, considering the case of drugs for neglected diseases, will be analysed taking into account, not only the Brazilian Industrial Property Act, but also the theoretical reference based on a normative political institutional perspective. Finally, the constructive interpretive approach is applied as a means of reconfiguring the legal coherence of patentability of second medical use drugs in a social context of inclusiveness and technological innovation which are the basic principles derived from the Brazilian constitutional system.

\section{INTEGRITY AND IDENTITY IN LAW: A METHODOLOGICAL APPROACH}

The methodology applied to this research consists of an unobtrusive analysis of interpretive practice, whose aim is to unveil the 
underlying meaning of the patentability of second medical use drugs as far as innovation and scientific development are conceived as the primary goals of the Brazilian Industrial Property Rights Act. The method of content analysis is utilised to revisit, not only the industrial property rights rules, but also the administrative interpretation of these rules, taking the patentability of second medical use drugs as a unit of analysis.

The focus of this investigation is to evaluate as well as criticise the interpretive practice of administrative officials in the terms of analysing the legitimacy of approving second medical use drugs, considering the idea of identity in law. Relevant scientific data concerning the nature of second medical use drugs already patented will serve as a means of extracting the latent content of the interpretive practice applied by administrative officials. Obviously, in this specific case, the object of research is indirect data, which can be found on official governmental or scientific websites.

Following the dynamics of unobtrusive research, according to Babbie (2000), firstly, data analysis will be limited to written information publicly available referring to the state of art of second medical use drugs. Secondly, a qualitative data analysis will be conducted in order to either confirm or discard the initial hypothesis without disregarding the theoretical references elaborated. Thirdly, the process of interpretation of specific legal rules and official administrative agency action will be criticised so that inconsistencies between real facts and ideal normativity can be, at least, unveiled.

Identity in law as a synthetic theory, which fuses the ideal of integrity and the perspective of "living lawfully", indicates the most adequate interpretive practice for dealing with cases involving second medical use drugs. Methodologically, the legal dimension of this discussion involving the case of drugs for neglected diseases as well as the perspective of second medical use drugs has to be analysed taking into account, first of all, the actual state of art in this specific scientific field and the interpretation of up-to-date data regarding second medical use; secondly, the politics of legislation in terms of patent rights; thirdly, the interpretation of the Brazilian Industrial Property Rights Act; finally, the institutional interpretive prognosis of an effective and legitimate change in the attribution of legal monopoly to second medical use drugs in accordance with the Brazilian Industrial Property Rights Act.

The first step here before analysing the case of second medical use drugs is to conceptualize the theory of law as identity. It is relevant to consider as the first point of departure of identity in law the theory of law as integrity. Basing the argument of taking rights seriously on the Dworkian project of law as integrity, it is consistently articulated to add an institutional moral component to the traditional "dimension of fit" in order to reconstruct the process of legal interpretation in 
judicial and legislative practice. Obviously, Dworkin (1986, p. 18990) intends to define integrity, taking as a major value, the idea of a personified community, which means that morality is a qualifier of legal interpretation:

"Integrity, in contrast, insists that each citizen must accept demands on him, and may make demands on others, that share and extend the moral dimension of any explicit political decisions. Integrity therefore fuses citizens' moral and political lives: it asks the good citizen, deciding how to treat his neighbour when their interests conflict, to interpret the common scheme of justice to which they are both committed just in virtue of citizenship".

This extract suggests that a personified community requires sharing moral values as a means of reconstructing the idea of politics and justice. Integrity is founded on the idea of how the ideal of a community must be universalised to reveal the essential moral values which define, not only each individual as an independent identity, but also an institutional political background shared by each member of a community. Integrity in law demands a real commitment to intertwining moral values and the dimension of fit in the interpretive practice when applying the law. In fact, the process of interpreting the law, according to Dworkin (1986), can be compared metaphorically to the chain novel model which means that every decision, although taken at different times, is supposed to guard relative coherent relationship to previous ones so that the original plot is not corrupted. Succinctly, law as integrity represents an initial effort to reconfigure and conceive law as an interpretive practice, which is shaped and forged in the tension between legality and fraternal attitude. However, Dworkin (1986) does not indicate how this tension is supposed to promote relevant change in interpretive practice. Therefore, it is important to acknowledge the idea of identity from a social point of view so as to complement the moral dimension of Dworkin's theory.

According to Taylor (1989, p. 47), "our lives exist also in the space of questions, which only a coherent narrative can answer. In order to have a sense of who we are, we have to have a notion of how we have become". This narrative, which is conceived in the relationship with others, in a dialogical process, is paramount in understanding the formation of human identity. The identity of a self derives from a "web of interlocution" which grows in depth only if there is space for strong moral evaluation. In Taylor's social theory, morality incorporates not only what is right to do but also what is right to be. It is inconceivable 
to make qualitative distinctions of worth based, exclusively, on a guide to action. This qualitative distinction of worth requires a profound understanding of what kind of role righteousness plays as an essential component of the moral evaluation of a self. Thinking about the kind of life that is worth living is a relevant step towards the formation of a moral attitude of a self. Taylor's study of the making of modern identity serves to enlighten what is known as the moral dimension of Dworkin's idea of integrity in law. In order to elaborate legal interpretive practice beyond the exclusive dimension of fit, it is essential to think about what kind of individual you want to be as well as what kind of community you intend to have (DWORKIN, 1986). However, this is possible only if individuals are capable of reflective thinking, which consists of pondering about what is right to do and what is right to be. The quest for this moral dimension necessitates a real commitment to always being reflexive about the kind of human being a personified community values. Here lies the beginning of a legal practice based on identity. Following this reasoning, living lawfully will represent the last piece of this legal puzzle.

Living lawfully, according to Bankowski (2001), needs a truthful commitment to what is righteous. In order to achieve this ideal, it is, first of all, paramount to understand the rules under which humans live; secondly, it is essential to pay attention to the story that is told, to the particularity of each case presented to the jurist; thirdly, it is fundamental to reconstruct the meaning of legislation through, what Bankowski himself denominates, "parabolic reasoning"; finally, law and love will structure bridging institutions based on the possibility of going beyond a semantic interpretive legal perspective without disregarding the relevance of legality. A structural question arises: how can this theory be effectively applied in legal practice?

Parabolic reasoning is a methodological tool, which logically explains the underpinnings of Bankowski's theory. In spite of having been based on a Christian belief system, parabolic reasoning is easily conceived as an interpretive practice applied to Ancient Law. Bankowski (2001) exemplifies this specific reasoning, taking as a model of interpretive practice, the parable of the Good Samaritan. He relates Jesus's explanation given to the lawyer when asked what the content of Ancient Law was and what "acting in a neighbourly manner to people" meant. As a matter of fact, the lawyer wanted to put Jesus in a difficult position for he was suspected of disregarding Ancient Law. Nonetheless, Jesus responded to the lawyer showing a thorough understanding of the law as well as demonstrating the ability to interpret the law beyond a strict semantic approach. Jesus reconstructs the meaning of "neighbour" by telling the story of the Good Samaritan. According to the proposed interpretation, acting in a neighbourly manner signifies that you should 
leave your comfort zone so as to help someone in need. It means that the reason why help is granted is not because the other is vulnerable and wounded but it is because the helper grasps the true meaning of being at the same time autonomous and vulnerable in a risky society. According to Bankowski (2001), the other is not the Jew fallen among thieves but the Samaritan who runs the risk of putting himself in a vulnerable situation by helping the other on a dangerous road, as the road from Jericho to Jerusalem was known. Succinctly, parabolic reasoning can be constituted as a methodological instrument to execute critical reconstruction of legality by going beyond the law "within the context of the inside" (BANKOWSKI, 2001, p. 177).

Identity in law consists of a new line of legal reasoning for it encompasses the fraternal attitude of law as integrity and turns it into a methodological instrument for re-establishing a new rule of law under the risk of love. This tension between law and love, explored by Bankowski (2001), summarises an advanced level of methodological expertise in reevaluating the nature of legal interpretation in contemporary societies. Here lies the encounter between the methodology of content analysis and the methodology of identity in law. No matter what type of data one is dealing with, the process of extracting specific data from a certain context and re-interpreting the data in a new context of theoretical basis validates new traits of significance whose meaning could not have been constructed in a different context. So as to make the argument clearer, the act of interpreting legal rules, such as, the legitimacy and legality of second medical use drugs, is built under the methodological concept of extracting the original meaning of a certain rule and reconstructing it in a context of inclusiveness, social solidarity and love. Identity in law overcomes the theoretical obstacles of living lawfully and integrity in law by elucidating how legal rules are transformed and turned into a new law by taking into account the context of their application.

Metaphorically, Dworkin (1986) compares this aforementioned process with the chain novel, whereas Bankowski (2001) utilises for the same purpose the idea of a soap opera with new episodes being added. However, the best-updated metaphor for better describing this idea of identity in law is the remixing of different types of music. Although sampling without proper license is considered to be illegal by the lobby of the copyright music industry, it is a way of preserving the original source of a specific song, however, executed in a totally different manner. A good example is the Brazilian concept of "tecnobrega" which can take an entire original song, such as, "Crazy", from Gnarls Barkley, subsequently adding specific beats that will essentially transform the old song into a renewed expression of art which is more relevant to the social context in case. It is not nonsensical to say that this new song produced by Brazilians maintains the source of the 
original one, nonetheless with fragmentary elements of locality and specificity. Thus, a new identity for a song originally produced by an American band is creatively transformed. This sense of identity implies the possibility of creative reconstruction taking into consideration the interests, the needs and the prospects of a specific community. The quest for empirical fragments which complement the meaning of a legal rule can be compared to the quest for a specific beat that might change the sound of a song without discarding its original melody. In this sense, it is possible to see a strong similarity with parabolic reasoning and, above all, the possibility of formulating, in law, the differentiated unity, proposed by Bankowski (2001). The original song is re-contextualised, is not annihilated at all but is indeed merged in a context of a new beat. Identity in law is this possibility of managing the essence of a legal rule in a new context of social inclusiveness. Each individual of the community can recognise himself in the process of applying legal rules to others. Here lies identity in law as a methodological concept, which includes every single member of the community in the mechanism of creative legal reconstruction.

\section{SECOND MEDICAL USE AND DRUGS FOR NEGLECTED DISEASES}

\subsection{The case of second medical use}

Before analysing the relationship between second medical use and drugs for neglected diseases, it is relevant to verify the nature of the specific case of patent right of second medical use in the pharmaceutical field. It is important to reiterate the first basic question of this research, i.e., is it legally valid to grant exclusivity to second medical use components, according to the Brazilian Patent Rights Act?

Obviously, official data on the website of the National Institute of Industrial Property Rights (INPI) reveals a direct answer to this question (BRASIL, 2012). According to the INPI, the second medical use fulfils the legal requisites of patentability. The basic argument of officials from INPI is that whenever it is possible to apply the Swiss formula to the incremented drug derived from an original component already patented, legal monopoly ought to be granted. The WHO (2012), in accordance with its data basis, defines the Swiss formula in the following statement: "Use of X for the manufacture of a medicine to treat Y". This signifies that the drug is only considered to be fulfilling the requisite of novelty if and only if the same substance already patented in another component yields a new medicine to treat a new disease. Utilising this basic argument for attributing the right to patent to the inventor of a newly incremented drug, the officials from INPI believe that the original ground of a patent 
right is preserved, for the ideas of novelty and non-obviousness are fully respected by strict logical deduction. However, the formula does not express the adequate moral density of legal requisites, such as, novelty and non-obviousness. As a matter of fact, the officials are validating an instrumental methodological tool, which may simplify the process of legal interpretation in the field of Industrial Property Rights. It is a simplistic way of analysing an intricate case that might jeopardise the basic fundamentals and underpinnings of patent rights.

Observing the methodological tool developed above, it is logical to assert that the identity of industrial property rights is forged in a context of social inclusiveness and scientific development (innovation). Searching for the original fundamentals of patent rights signifies unveiling the idea of exclusivity as a means of fostering innovation in contemporary societies. Moreover, it means the regular process of attributing a right to the person responsible for a theoretical and practical effort to innovate in the field of science and nature. The Swiss formula does not add any kind of moral evaluation to the fundamentals of patent rights. It is necessary to reformulate the concept of novelty and nonobviousness as different facets of the same structure. Both criteria are intertwined. They should not be analysed separately. In terms of law as identity, a second medical use component ought to be legally valid if it represents an immaterial result derived from a theoretical and practical effort in the construction of something new added to the actual state of art. The logic here is the same as the idea aforementioned about the remixing of original songs. It orientates the interpreter to verify the validity of a certain invention based on the fact that the originality of legal rules is preserved, even though it is subjected to a new context of application. The result of this process of invention, if originally conceived to create a new product in a different environment of application, fulfils the basic grounds of industrial property rights, i.e., the protection of innovative ideas and products. The fundamentals here are not to reinforce the legal monopoly of pharmaceutical industries, but they consist of an archaeological procedure of detecting the novelty of an immaterial result derived from a substantial theoretical effort in order to add new elements to medical science.

\subsection{The relationship between second medical use and drugs for neglected diseases}

Once it is demonstrated that the new component, although derived from an already patented drug, ought to be patented due to the substantial theoretical and practical effort to elaborate something new as far as the state of art is concerned, it is important to face the second relevant question raised during the research, i.e., is it legally 
and logically coherent through ordinary interpretation to validate the second medical use as an incentive to develop and produce drugs for neglected diseases?

According to data extracted from the work of Chong and Sullivan Jr. (2007), it is neither logical nor juridical to affirm that there is a relationship between second medical use and drugs for neglected diseases. In order to exemplify the argument, a supplementary table developed by the authors served as indirect data to evaluate the possibility of using a second medical use mechanism as a means of fostering the development of drugs for neglected diseases. The supplementary table contains interesting examples of incremented drugs. Methodologically, data from the supplementary table was checked against the official website of WIPO (World Intellectual Property Organisation) so as to confirm its legal validity. Furthermore, the purpose of this was to verify if there had been any granting of patent rights to the second medical use drugs in case.

The existence of second medical use drugs for global diseases, as shown in the table, reinforces the necessity for creating new public incentives for the development of drugs for neglected diseases, as the market itself will not mechanically and organically structure new forms of drugs for these diseases. There is no economic interest in the production of these kinds of drugs. In this context, it is necessary to reconfigure the nature of industrial property rights legislation. Innovation is not taken as a primary goal in the specific case of drugs for neglected diseases. The latent content of the data expressed in the supplementary table emphasises the need for new legal practice in the pharmaceutical field.

This research pinpoints the inconclusiveness of evaluating cost reduction in the development of drugs for neglected diseases in the case of utilising second medical use as a means of reducing transaction costs ${ }^{2}$. There is no evidence in the latent content of the data collected that can in any way confirm any type of cost reduction in the development of these drugs. As a matter of fact, it might be too costly to, first of all, evaluate all the different costs involved in the process of research, development and production of drugs for neglected diseases, and secondly, relate all the costs involved to the case of second medical use. Thus, it is questionable to affirm that second medical use is a relevant mechanism to reduce transaction costs in the production of drugs for neglected diseases. In fact, the argument of transaction costs demonstrates the infeasibility of calculating all the possible costs involved in the process of research and development of drugs for neglected diseases. Furthermore, from a juridical and a moral point of view, this kind of argument does not

2 Coase (1993) defines the expression "transaction costs" when conceptualizing the nature of the firm. 
prove to be effective in the process of relating second medical use to the development of drugs for neglected diseases. Once a number of second medical use drugs developed for global diseases can be spotted in the supplementary table above, it is possible to assert that second medical use drugs has neither economic nor social efficacy in the process of fostering new research and development of drugs for neglected diseases.

It must be noted that the prohibition of patenting the second medical use drugs, as the majority of the Brazilian National Congress intends to do (BRASIL, 2012a, b, c), does not suffice to optimise the development of drugs for neglected diseases. This change in the politics of legislation is rather inconsistent as well as incoherent as far as identity in law is concerned. Indeed, abolishing rights already consolidated in the Brazilian Industrial Property Rights Act is not an adequate mechanism to implement the right to effective health care, through more efficient and less expensive pharmaceutical drugs. In fact, the basic fundamentals of the Brazilian Industrial Property Rights Act are constitutionally oriented. In this sense, the prohibition of second medical use ought to be interpreted as a constitutional offence taking into account the fundamental underpinning, which informs the moral density of legal rules, i.e., the right to innovate and the right to scientific development. Deliberately excluding the legal possibility of patenting the second medical use drugs represent the corruption of a constitutional principle that is based upon the tension between economic and social rights. Therefore, this constitutes a radicalisation of legality as the only possible via for reconfiguring the juridical system so as to achieve social aims. The interpretive practice, based on the theory of identity in law, rejects any attempt to criminalise or prohibit certain behaviours as a result of legislative politics in order to achieve a better quality of life. It is not morally justifiable to implement social goals in detriment of constitutional rights. 
SUPPLEMENTARY TABLE (extracted from Chong; Sullivan Jr. (2007))

\begin{tabular}{|c|c|c|}
\hline Drug & Original disease & New disease \\
\hline Amphotericin & $\begin{array}{l}\text { Antifungal } \\
\text { Interferes with } \\
\text { fungal membranes } \\
\text { by binding to cell } \\
\text { membrane sterols }\end{array}$ & Leishmaniasis \\
\hline Arsenic & $\begin{array}{l}\text { "Oldest drug in } \\
\text { the world } 1 " \\
\text { Used in early } \\
20^{\text {th }} \text { century to } \\
\text { treat tuberculosis } \\
\text { and syphilis }\end{array}$ & $\begin{array}{l}\text { Acute promyelocytic } \\
\text { leukemia } 1 \\
\text { Degrades } P M L-R A R \\
\text { fusion protein }\end{array}$ \\
\hline Ceftriaxone & $\begin{array}{l}\text { Antibiotic } \\
\text {-lactam inhibits } \\
\text { bacterial cell } \\
\text { wall synthesis }\end{array}$ & $\begin{array}{l}\text { Amyotrophic Lateral } \\
\text { Sclerosis } 2 \\
\text { Increases glutamate } \\
\text { transporter expression }\end{array}$ \\
\hline Dapsone & $\begin{array}{l}\text { Leprosy }{ }^{3} \\
\text { Inhibits folic } \\
\text { acid synthesis }\end{array}$ & $\begin{array}{l}\text { Malaria } \\
\text { Combined with } \\
\text { chloroproguanil in } \\
\text { LapDap; approved by UK } \\
\text { for treatment of malaria }{ }^{4}\end{array}$ \\
\hline DB289 & Pneumocystis ${ }^{5}$ & $\begin{array}{l}\text { Malaria and early stage } \\
\text { African Trypanosomiasis }{ }^{5} \text {. }\end{array}$ \\
\hline Eflornithine & $\begin{array}{l}\text { Cancer } \\
\text { Suicide inhibitor } \\
\text { of ornithine } \\
\text { decarboxylase, } \\
\text { blocking polyamine } \\
\text { biosynthesis. Failed } \\
\text { in clinical trials }^{6} \text {. }\end{array}$ & $\begin{array}{l}\text { African trypanosomes } \\
\text { Inhibits protozoan } \\
\text { ornithine decarboxylase } \\
\text { but is specific for African } \\
\text { trypanosomes due to low } \\
\text { blood polyamine levels } \\
\text { G. Established treatment. }\end{array}$ \\
\hline
\end{tabular}




\begin{tabular}{|c|c|c|}
\hline Fosmidomycin & $\begin{array}{l}\text { Urinary tract } \\
\text { infections } \\
\text { Inhibits isoprenoid } \\
\text { synthesis }{ }^{7} \text {. }\end{array}$ & $\begin{array}{l}\text { Antimalarial } \\
\text { Nonmevalonate } \\
\text { pathway of isoprenoid } \\
\text { biosynthesis identified } \\
\text { in P. falciparum using } \\
\text { genomic techniques } 3{ }^{3} \text {. } \\
\text { Currently in clinical trials } \\
\text { alone and in combination } \\
\text { with clindamycin }{ }^{8,9} \text {. }\end{array}$ \\
\hline Fumagillin & $\begin{array}{l}\text { Antiamebic } \\
\text { Unknown mechanism. }\end{array}$ & $\begin{array}{l}\text { Anti-cancer angiogenesis } \\
\text { inhibitor } \\
\text { Blocks endothelial cell } \\
\text { growth by inhibiting } \\
\text { type II methionine } \\
\text { aminopeptidase }{ }^{10} \text {. TNP- } \\
470 \text {, a fumagillin analog, } \\
\text { is currently in Phase } \\
\text { III clinical trials for } \\
\text { brain, breast, cervical } \\
\text { and prostate cancer }{ }^{11} \text {. }\end{array}$ \\
\hline Miltefosine & $\begin{array}{l}\text { Cancer } \\
\text { May induce } \\
\text { apoptosis by } \\
\text { inhibiting lipid } \\
\text { biosynthesis }^{12} \text {. }\end{array}$ & $\begin{array}{l}\text { Visceral leishmania } \\
\text { Unknown mechanism. } \\
\text { Registered for use in } \\
\text { India in } 2002^{13} \text {. }\end{array}$ \\
\hline Minocycline & $\begin{array}{l}\text { Antibiotic } \\
\text { Blocks entry of the } \\
\text { aminoacyl tRNA } \\
\text { into the ribosome. }\end{array}$ & $\begin{array}{l}\text { Amyotrophic } \\
\text { lateral sclerosis } \\
\text { Inhibits cytochrome C } \\
\text { release from mitochondria. } \\
\text { Delays disease onset } \\
\text { and extends survival } \\
\text { of ALS mice }{ }^{\text {I. }}\end{array}$ \\
\hline $\begin{array}{l}\text { Non-steroidal } \\
\text { anti- } \\
\text { inflammatory }\end{array}$ & $\begin{array}{l}\text { Anti-inflammatory } \\
\text { Cyclooxygenase } \\
\text { inhibitor }\end{array}$ & $\begin{array}{l}\text { Alzheimer's disease } \\
\text { Reduce brain A } \\
\text { levels and amyloid } \\
\text { plaque burden }{ }^{14}\end{array}$ \\
\hline Paromomycin & $\begin{array}{l}\text { Amebicide }^{15} \\
\text { Oligosaccharide } \\
\text { antibiotic }\end{array}$ & $\begin{array}{l}\text { Visceral leishmaniasis }{ }^{12} \\
\text { Administered by injection }\end{array}$ \\
\hline
\end{tabular}




\begin{tabular}{|l|l|l|}
\hline Pentamidine & $\begin{array}{l}\text { Pneumocystis } \\
\text { carinii pneumonia }\end{array}$ & $\begin{array}{l}\text { Early stage trypanosome } \\
\text { infection and antimony } \\
\text { resistant leishmaniasis } 16\end{array}$ \\
\hline Quinacrine & $\begin{array}{l}\text { Antimalarial } \\
\text { Interferes with heme } \\
\text { crystallization 17 }\end{array}$ & $\begin{array}{l}\text { Prion diseases } \\
\text { Potently inhibits prion } \\
\text { formation 18. Anecdotal } \\
\text { reports of improvement in } \\
\text { patients with Creutzfeldt- } \\
\text { Jakob disease 19. }\end{array}$ \\
\hline Retinoic acid & Acne & $\begin{array}{l}\text { Acute promyelocytic } \\
\text { leukemia } \\
\text { Activates transcription } \\
\text { of genes involved in } \\
\text { differentiation 20 }\end{array}$ \\
\hline $\begin{array}{l}\text { Serotonin } \\
\text { receptor } \\
\text { antagonists }\end{array}$ & Antipsychotic & $\begin{array}{l}\text { Progressive multifocal } \\
\text { leukoencephalopathy } \\
\text { Inhibit human } \\
\text { polyomavirus (JCV) } \\
\text { infection of glial cells }{ }^{21}\end{array}$ \\
\hline Thalidomide & $\begin{array}{l}\text { Sedative } \\
\text { Potent teratogen }\end{array}$ & $\begin{array}{l}\text { Cancer }{ }^{22} \\
\text { Inhibits angiogenesis }\end{array}$ \\
\hline
\end{tabular}

\section{REFERENCES:}

1. Zhu, S. et al. Minocycline inhibits cytochrome c release and delays progression of amyotrophic lateral sclerosis in mice. Nature 417, 74-8 (2002).

2. Rothstein, J. D. et al. Beta-lactam antibiotics offer neuroprotection by increasing glutamate transporter expression. Nature 433, 73-7 (2005).

3. Jomaa, H. et al. Inhibitors of the nonmevalonate pathway of isoprenoid biosynthesis as antimalarial drugs. Science 285, 1573-6 (1999).

4. Lang, T. \& Greenwood, B. The development of Lapdap, an affordable new treatment for malaria. Lancet Infect Dis 3, 1628 (2003).

5. Yeates, C. DB-289 Immtech International. IDrugs 6, 1086-93 (2003).

6. Marton, L. J. \& Pegg, A. E. Polyamines as targets for therapeutic intervention. Annu Rev Pharmacol Toxicol 35, 55-91 
(1995).

7. Shigi, Y. Inhibition of bacterial isoprenoid synthesis by fosmidomycin, a phosphonic acid-containing antibiotic. J Antimicrob Chemother 24, 131-45 (1989).

8. Missinou, M. A. et al. Fosmidomycin for malaria. Lancet 360, 1941-2 (2002).

9. Borrmann, S. et al. Fosmidomycin-clindamycin for Plasmodium falciparum Infections in African children. J Infect Dis 189, 901-8 (2004).

10. Griffith, E. C. et al. Methionine aminopeptidase (type 2) is the common target for angiogenesis inhibitors AGM-1470 and ovalicin. Chem Biol 4, 461-71 (1997).

11. Kruger, E. A., and Figg, W.D. TNP-470: an angiogenesis inhibitor in clinical development for cancer. Expert Opin Investig Drugs 9, 1383-96 (2000).

12. Fidock, D. A., Rosenthal, P. J., Croft, S. L., Brun, R. \& Nwaka, S. Antimalarial drug discovery: efficacy models for compound screening. Nat Rev Drug Discov 3, 509-20 (2004).

13. Sundar, S. et al. Oral miltefosine for Indian visceral leishmaniasis. N Engl J Med 347, 1739-46 (2002).

14. Guerin, P. J. et al. Malaria: current status of control, diagnosis, treatment, and a proposed agenda for research and development. Lancet Infect Dis 2, 564-73 (2002).

15. Botero, D. Chemotherapy of human intestinal parasitic diseases. Annu Rev Pharmacol Toxicol 18, 1-15 (1978).

16. Docampo, R. \& Moreno, S. N. Current chemotherapy of human African trypanosomiasis. Parasitol Res 90 Supp 1, S10-3 (2003).

17. Chong, C. R. \& Sullivan, D. J., Jr. Inhibition of heme crystal growth by antimalarials and other compounds: implications for drug discovery. Biochem Pharmacol 66, 2201-12 (2003).

18. Korth, C., May, B. C., Cohen, F. E. \& Prusiner, S. B. Acridine and phenothiazine derivatives as pharmacotherapeutics for prion disease. Proc Natl Acad Sci U S A 98, 9836-41 (2001).

19. Nakajima, M. et al. Results of quinacrine administration to patients with Creutzfeldt-Jakob disease. Dement Geriatr Cogn Disord 17, 158-63 (2004).

20. Fang, J. et al. Treatment of acute promyelocytic leukemia with ATRA and As2O3: a model of molecular target-based cancer therapy. Cancer Biol Ther 1, 614-20 (2002).

21. Elphick, G. F. et al. The human polyomavirus, JCV, uses serotonin receptors to infect cells. Science 306, 1380-3 (2004).

22. D'Amato, R. J., Loughnan, M. S., Flynn, E. \& Folkman, J. Thalidomide is an inhibitor of angiogenesis. Proc Natl Acad Sci 
U S A 91, 4082-5 (1994).

Table reference: CHONG, Curtis R.; SULLIVAN Jr., David J. New uses for old drugs. Nature, vol. 448, London, August $9^{\text {th }}$, 2007. Available on: <http://www.nature.com/nature/journal/v448/ n7154/suppinfo/448645a.html>. Access on April 16th, 2012. Certified in: World Intellectual Property Organization: Data basis. Available on: <http://www.wipo.int/patentscope/search/en/search. jsf;jsessionid=834CBEE201F706631C3423F081322201.wapp2>. Access on April15th, 2012.

Finally, identity in law demands a remix of old legal standards with new contexts of social inclusiveness. This methodological analysis of legal reasoning substantiates the need for a change in the interpretive practice of industrial property rights. So as to re-adequate the traditional legal standards to the social needs of development of drugs for neglected diseases, it is relevant to orient public financial support to policies towards, not only the scientific development of drugs for neglected diseases, but also the serial production of cheaper drugs for the poor who suffer from neglected diseases. State intervention ought to be reconstructed in order to create an environment of social inclusiveness without jeopardising the attribution of individual rights. Indeed, identity in law requires an attitudinal respect of administrative officials and legislators towards the implementation of the Dworkian axiom, i.e., taking constitutional rights seriously.

\section{Conclusions}

From a methodological point of view, it is crucial to conclude that the analysis of latent content related to second medical use substances revealed the actual scientific state of medical science. According to the data extracted from scientific medical research, it is logical to consider that there is no evidence that second medical use drugs can be used as an instrument to induce the research and the development of drugs for neglected diseases. However, it cannot be denied the legitimacy and the legality of second medical use drugs according to the interpretive practice derived from the proper legislation.

As far as the analytical system of concepts founded on the idea of identity in law is concerned, the qualitative research here developed demonstrated that state intervention in the field of drug research and production ought to be structured in order to coherently articulate public policies, which can induce the pharmaceutical market to produce drugs for neglected diseases. Nevertheless, the process of state intervention should not jeopardise the attribution of rights in the case of second medical use drugs. 
Finally, it is not legally and logically coherent through ordinary interpretation to confirm the second medical use as an incentive to develop and produce drugs for neglected diseases. Drugs for neglected diseases can be obtained from second medical use experiments. Nonetheless, this does not prove that second medical use is an efficient mechanism to promote the development of drugs for these diseases. In fact, new kinds of inducement of public policies towards the importance of providing scientific effort for the production of drugs for neglected diseases should be elaborated in order to achieve balance between the constitutional right to patent and the constitutional right to proper health care. It is a hard case of conflicting values, which ought to be resolved taking into account the original fundamentals of individual rights without threatening the social right to health care.

\section{REFERENCES}

BABBIE, Earl. The practice of social research. 9. ed. Belmont: Wadsworth/Thomson learning, 2000.

BANKOWSKI, Zenon. Living lawfully: love in law and law in love. Dordrecht: Kluwer Academic Publishers, 2001.

BANKOWSKI,Zenon. University ofEdinburgh.Edinburgh.Available online: http://www.law.ed.ac.uk/staff/zenonbankowski_21.aspx. Downloaded in February, 2012.

BRASIL. Instituto Nacional da Propriedade Industrial. Data basis of INPI. Patent Basis. Available on: <http://pesquisa.inpi.gov.br/ MarcaPatente/jsp/servimg/validamagic.jsp?BasePesquisa $=$ Patentes $>$. Access on February $16^{\text {th }}, 2012$.Updated on: 02/14/2012.

BRASIL. Desenvolvimento Econômico discute patentes de segundo uso. Agência CâmaradeNoticias. BrasíliaApril 13 ${ }^{\text {th }}$,2012. Availableon:http://www2. camara.gov.br/agencia/noticias/CIENCIA-E-TECNOLOGIA/414621DESENVOLVIMENTO-ECONOMICO-DISCUTE-PATENTES-DESEGUNDO-USO.html Access on April 14 ${ }^{\text {th }}, 2012$ a.

BRASIL. Anvisa e deputados criticam INPI quanto a patentes de segundo uso . Agência Câmara de Notícias. Brasília; October, 27 th, 2009. Available on: http://www2.camara.gov.br/agencia/noticias/ CIENCIA-E-TECNOLOGIA/142041-ANVISA-E-DEPUTADOSCRITICAM-INPI-QUANTO-A-PATENTES-DE-SEGUNDO-USO. html. Access on April 14 ${ }^{\text {th }}, 2012$ b.

BRASIL. Governo diverge sobre concessão de patente de $2^{\circ}$ uso. Brasília. July $3^{\text {rd }}$, 2008 Agência Câmara de Notícias. Available on: http://www2.camara.gov.br/agencia/noticias/124505.html. Access on April 14 ${ }^{\text {th }}, 2012 \mathrm{c}$. 


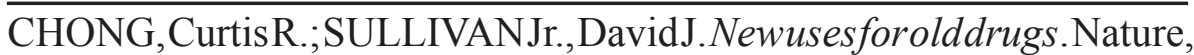
vol. 448. Londres, ago. 2007. Disponível em: <http://www.nature.com/ nature/journal/v448/n7154/suppinfo/448645a.html>. Acesso em: 16 abr. 2012. Certificado em: World Intellectual Property Organization: banco de dados. Disponível em <http://www.wipo.int/patentscope/search/ en/search.jsf;jsessionid=834CBEE201F706631C3423F081322201. wapp2>. Acesso em 15 abr. 2012.

COASE, Ronald. The nature of the firm. in WILLIAMSON, Oliver \& WINTER, Sidney G.(ed.) The nature of the firm: origins, evolution and development. $2^{\text {a }}$ ed. New York : Oxford university press, 1993

DWORKIN, Ronald. Law's Empire. Oxford: Hart Publishing Press, 1986.

1985.

. A matter of principle. Cambridge: Harvard University Press, 1977.

. Taking rights seriously. Cambridge: Harvard University Press, 2006.

. Justice in robes. Cambridge: Belknap Harvard University Press,

HABERMAS, Jürgen. The theory of communicative action: reason and the rationalization of society. Translated by Thomas McCarthy. Boston: Beacon, 1984.

. The theory of communicative action: lifeworld and system: a critique of functionalist reason. Translated by Thomas McCarthy. Boston: Beacon, 1987.

. Between facts and norms: contributions to a discourse theory of law and democracy. Translated by William Rehg. Cambridge: MIT, 1996.

. The inclusion of the other: studies in political theory. Edited by Ciaran Cronin and Pablo de Grieiff, Cambridge: MIT, 1998.

HART, H. L. A. The concept of Law. $2^{\text {nd }}$ ed. New York: Oxford university Press, 1994.

MÉDECINS SANS FRONTIÈRES. Desequilíbrio Fatal: A crise de pesquisa e desenvolvimento de drogas para doenças negligenciadas. Available on: <www.msf.Org.br/campanha/desequilíbrio.pdf $>$. Accessed on: May 25 th 2010.

MORAN, M. A breakthrough in R\&D for neglected diseases: new ways to get the drugs we need, PLoS Medicine, v.2, i. 9, 2005, pp. 828-32, Available at: < http://www.plosmedicine.org/article/info:doi/10.1371/ journal.pmed.0020302>. Downloaded on: March 25 ${ }^{\text {th }}, 2011$. 
OPREA, L.; BRAUNACK-MAYER, A.; GERICKE, C. A. Ethical issues in funding research and development of drugs for neglected tropical diseases, Journal of Medical Ethics, v. 35, n. 1, pp. 310-4, 2009. PÉCOUL, B. Government action needed to step up research and development for world's most neglected diseases. Available at: < http:// www.dndi.org/images/stories/pdf_scientific_pub/2005/pecoul_exper_ rev_anti_infec_ther2005.pdf $>$ Downloaded on: March 25 th $20 \overline{1} 1$.

SPENCE, Michael. Intellectual property. New York: Oxford university press, 2007.

TAYLOR, Charles. Sources of the self: the making of the modern identity. Cambridge: Harvard University Press, 1989.

. The ethics of authenticity. Cambridge: Harvard University Press, 1991.

. Human agency and language: philosophical papers I. Cambridge: Cambridge university press, 1985.

WEINBERGER, Ota. Law, institution, and legal politics: fundamental problems of legal theory and social philosophy. Dordrecht : Kluwer Academic Publishers, 1991.

WHO (2000). World Health Organization. WHO Data Basis. Swiss formula: Available on: < http://apps.who.int/medicinedocs/fr/d/Jh2963 e/6.3.2.html\#Jh2963e.6.3.2>. Access on April 17 ${ }^{\text {th }}, 2012$. 